\title{
FATIGUE LIFE ASSESSMENT OF SELECTED STRUCTURAL ELEMENTS OF MI-24 HELICOPTER
}

\author{
Robert Baraniecki \\ Malgorzata Kaniewska \\ Andrzej Leski
}

Air Force Institute of Technology, Warsaw, Poland

\begin{abstract}
In order to ensure the integrity of the structure, it is important to determine the actual loads that act on individual elements and their influence on fatigue life. The article demonstrates how to determine the fatigue life of selected elements of the Mi-24 helicopter. In addition, the work indicates the potential location of damage. In calculations, the actual levels of loads acting on the elements during the flight were used. The entire test was performed using the numerical analysis, which greatly helped reduce the time of the project. Fatigue life was determined using the MSC. FATIGUE program with the Palmgren - Miner linear damage accumulation rule.
\end{abstract}

\section{INTRODUCTION}

The aim of this work is to assess fatigue life of selected structural elements of the Mi-24 helicopter based on the real load spectra. Determination of the actual load spectra that act on individual structural elements is crucial to fatigue life estimation. This is due to the variables inflight load spectra. The load spectra for Polish Mi-24 helicopters were developed based on flight test results and an analysis of operational usage of these helicopters in the Polish Army.

Calculation of the fatigue damage for complex elements in an analytical way is primarily very time-consuming and problematic. By contrast, the numerical analysis can reproduce any shape, however, it is necessary to define the correct boundary conditions. In this paper, a methodology for the numerical fatigue life assessment is presented. Here are the selected structural elements together with the names of the related spectra:

- $\quad$ ELEMENT1 - Lever arm of swashplate collective pitch control of helicopter rotor,

- $\quad$ ELEMENT2 - Secondary strut of main gear support frame,

- $\quad$ ELEMENT3 - Primary strut of main gear support frame,

- $\quad$ ELEMENT4 - Pull rod of longitudinal control,

- ELEMENT5 - Pull rod of lateral control,

- ELEMENT6 - Lever arm of swashplate collective pitch control of helicopter rotor,

- $\quad$ ELEMENT7 - Pull rod of directional control.

This work aims at calculating the potential fatigue damage and estimating the remaining service life of these elements. For this purpose, the Palmgren-Miner rule of linear damage accumulation is applied. The analysis presented below is based on the SN curve (Wöhler) approach and the amount of damage is directly proportional to the number of loading cycles for a particular amplitude.

The S-N curve determines interdependence between fatigue life and amplitude of fatigue cycles. The S-N curve is developed on the basis of experimental results. The actual data obtained 
from the fatigue test prove a scatter of results. The mean S-N curves are developed by means of the approximation technique. Thus a half of tested coupons broke earlier than the mean S-N had indicated.

The mean S-N curve should not be directly used for fatigue life assessment in aeronautical industry because it gives result with $50 \%$ confidence level. To increase this confidence level it is necessary to apply a safety factor. One common solution is applying the safe S-N curve instead of the mean S-N curve during calculations[8].

The safe curve S-N can be developed if some safety factors $\eta_{N}$ i $\eta_{S}$ are applied to the mean S-N curve.

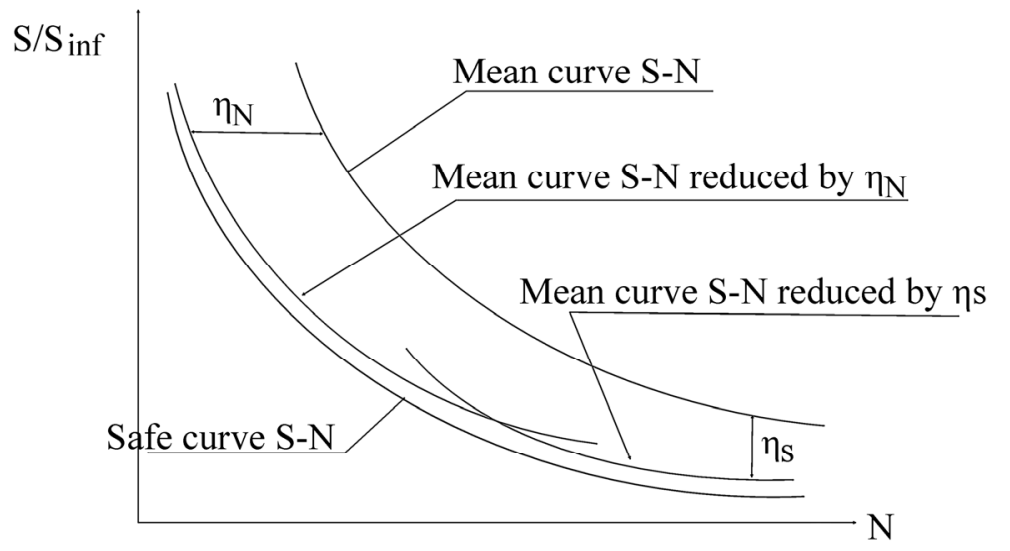

Fig.1. Graphical development of safe $S$-N curve

$\eta_{\mathrm{N}}-$ safety factor for life in low life area of curve $S-N$

$\eta_{\mathrm{S}}-$ safety factor for stress in high life area of curve $S-N$

\section{FATIGUE LIFE ASSESSMENT}

\subsection{Flight test instrumentation}

The actual load spectra were developed based on flight test results. All selected elements were taken off the helicopter. The strain gauges were glued on the chosen surfaces. Then a calibrating procedure was carried out using laboratory facilities. During this procedure loads were applied by the MTS testing machine and signals from the strain gauges were recorded. As a result of the calibrating procedure, the regression equations were developed. Using these equations, the forces acting on the elements during flight can be calculated based on the recorded strain gauges signals.

The flight test programme consisted of many tasks. The measurement of load in the selected structural elements was one of the tasks. The KAM-500 flight recorder was used during flight tests. Flight tests were performed by Polish Air Force Institute of Technology in 2009. Selected localizations of strain gauges are presented in figure 2 .

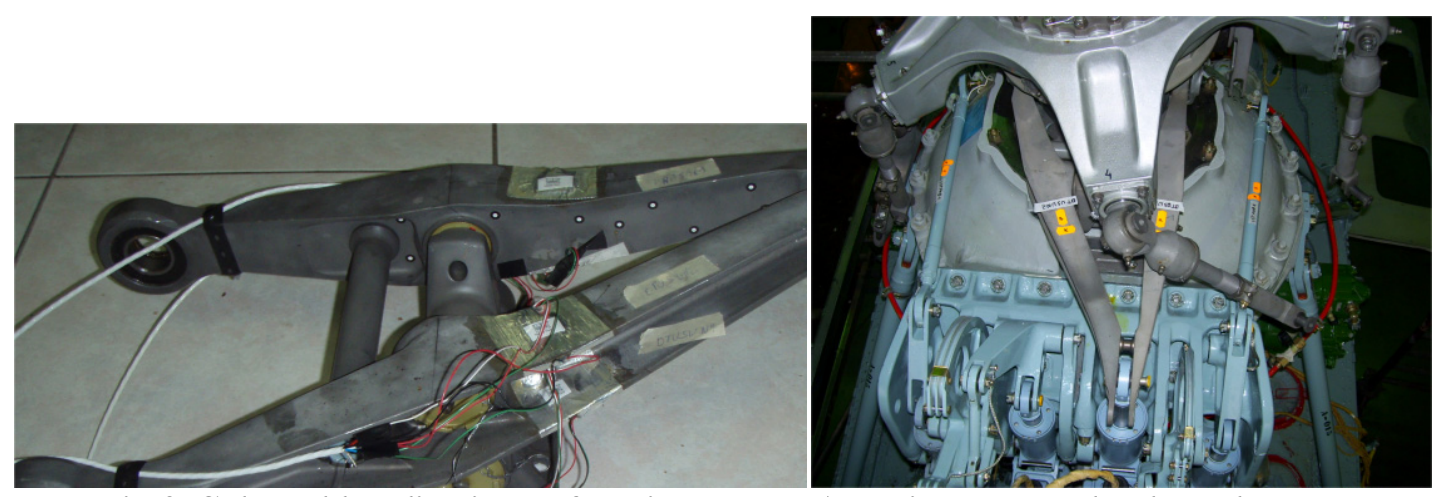

Fig.2. Selected localizations of strain gauges a) strain gauges glued on element; b) selected localizations (before instrumentation) 


\subsection{FEM Models of elements}

Since the available technical documentation was not sufficient to develop detailed FE models, the optical scanner 3D ATOS III (Advanced Topometric System) was used to capture the shape of the elements. The scanner projects parallel lines on a measured element while two high resolution cameras record their deformations on a scanned surface. Based on the recorded images the computer software GOM creates a digital representation of the scanned surface in 3D visualisation. The measured shapes can be converted to triangular representation and they can be used by various CAD/CAM software eg. Unigraphics. In figures 3 and 4, the scanned elements and their boundary represented models are shown. All boundary represented models were developed by means of Unigraphics software.

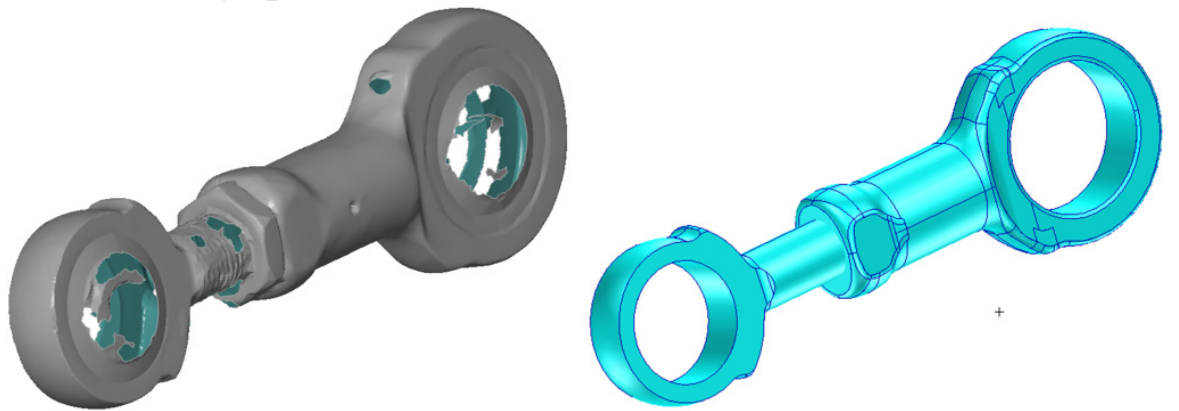

Fig.3. Example 1: a) scanning result; b) boundary represented
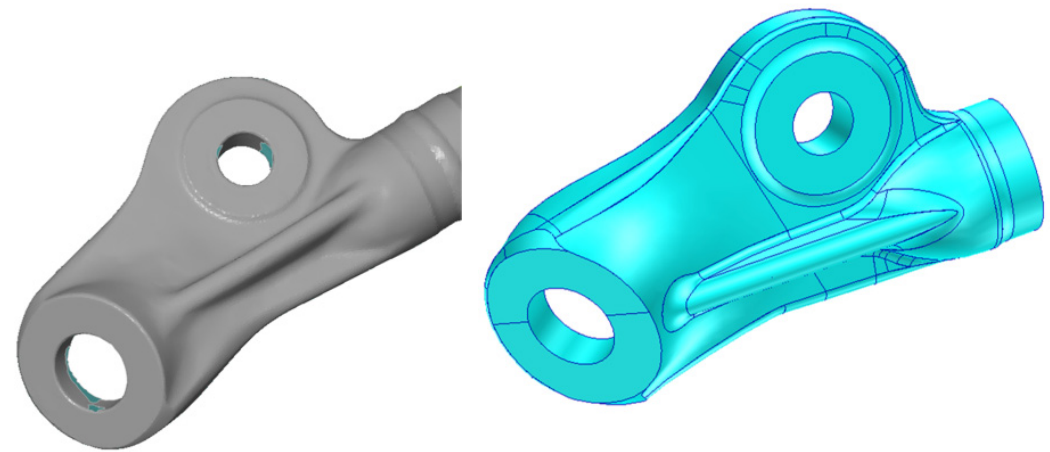

Fig.4. Example 2: a) scanning result; b) boundary represented model

Based on the boundary represented models the FE models were developed in the MSC.Patran environment. The following table shows the number of nodes and elements created for each element. The elements are shown in figures $5-10$.
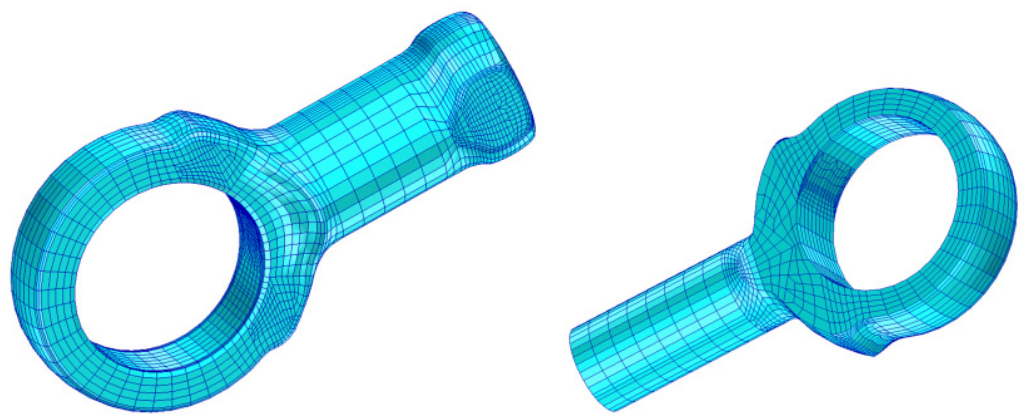

Fig. 5. ELEMENT1 - part1 and part2 


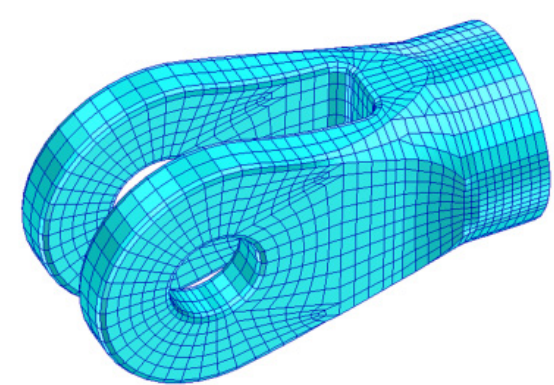

Fig. 6. ELEMENT2

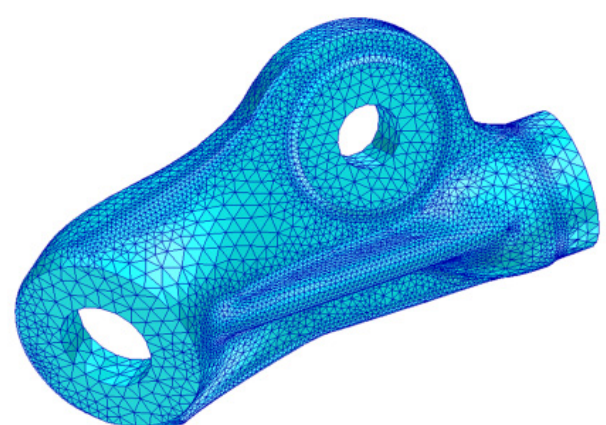

Fig. 7. ELEMENT3

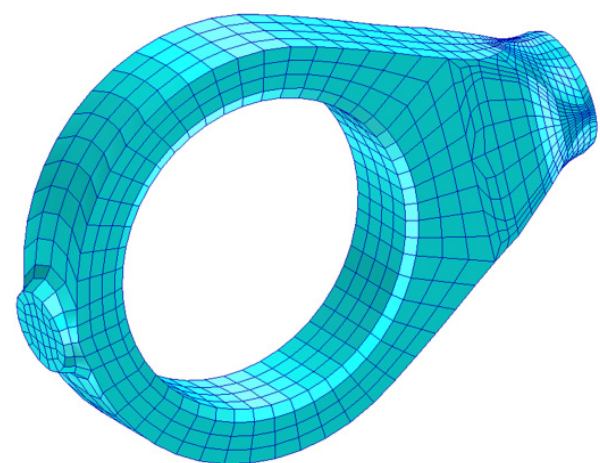

Fig. 8. ELEMENT4 and ELEMENT5

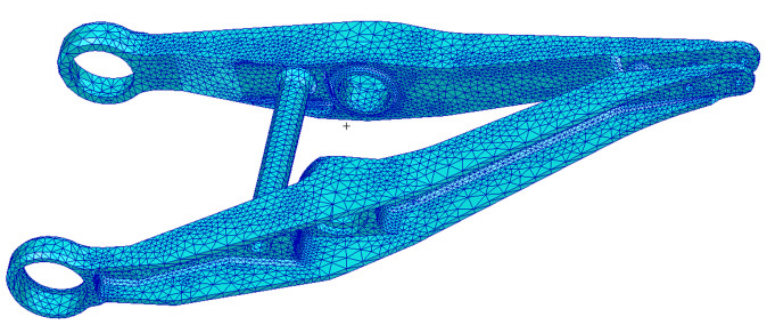

Fig. 9. ELEMENT6
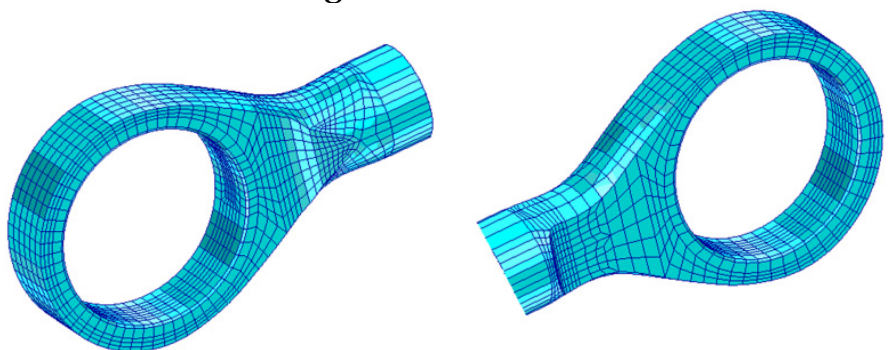

Fig. 10. ELEMENT7 - part1 and part2 
Tab. 1. The number of nodes and finite elements in FEM models [7]

\begin{tabular}{|c|c|c|c|}
\hline No. & Model MES & Number of nodes & $\begin{array}{c}\text { Number of elements } \\
\text { (type of elements) }\end{array}$ \\
\hline $\mathbf{1}$ & ELEMENT2 & 10080 & 11740 (hex8, wedge6, quad4, tria3) \\
\hline $\mathbf{2}$ & ELEMENT3 & 17568 & $94784($ tet4, tria3) \\
\hline $\mathbf{3}$ & ELEMENT4, ELEMENT5 & 4622 & 5616 (hex8, wedge6, quad4, tria3) \\
\hline $\mathbf{4}$ & ELEMENT1 (part 1) & 12486 & 14044 (hex8, wedge6, quad4, tria3) \\
\hline $\mathbf{5}$ & ELEMENT1 (part 2) & 6813 & 8080 (hex8, wedge6, quad4, tria3) \\
\hline $\mathbf{6}$ & ELEMENT7 (part 1) & 3299 & 4144 (hex8, wedge6, quad4, tria3) \\
\hline $\mathbf{7}$ & ELEMENT7 (part 2) & 8241 & 10136 (hex8 i quad4) \\
\hline $\mathbf{8}$ & ELEMENT6 & $\mathbf{1 7 8 6 8}$ & 92851 (tet4, tria3) \\
\hline
\end{tabular}

\section{Boundary conditions}

Node displacements and element pressure were used for boundary condition definitions. FEM models of the element 3 had restrained nodes in the mounting holes. The movements of half of the inner surface of the holes for mounting screws was suspended (Figure 11a-I) and the upper surface of the hole was blocked in the vertical direction (Fig. 11-II). These elements were charged with two forces acting along the primary and secondary struts (Fig. 11b). Based on flight test results the assumption was made that both forces act proportionally during helicopter flight [7]. Thus only one load case was analyzed for this element.
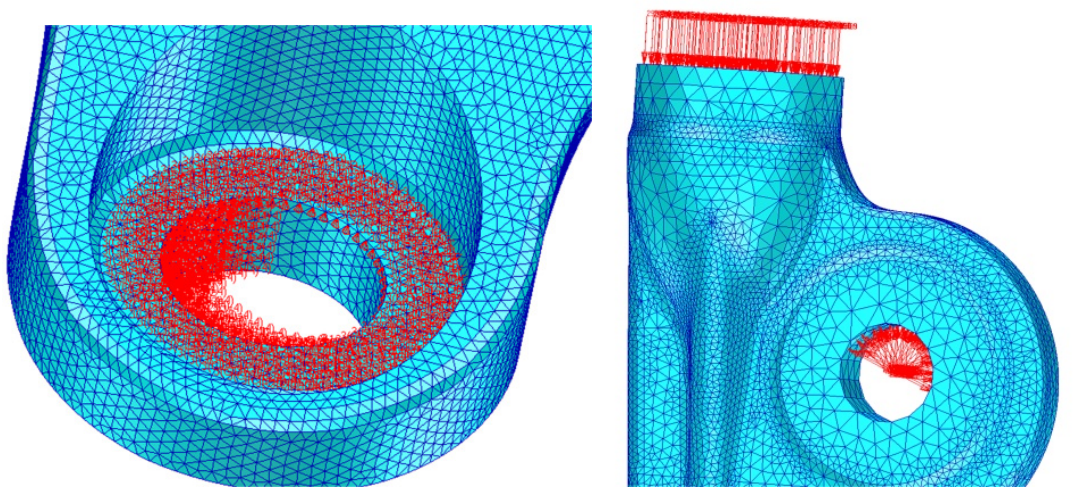

Fig. 11. Boundary condition of model element3: a) blocked displacement on the surface where the contact with the bolt occurs: I- the half inner surface of the hole; II- the outer surface of the hole; b) Load forces (pressure) acting along the primary and secondary struts

Similar boundary conditions were applied to other FE models. Usually, the nodes on the surface of the struts cross-section were fixed while distributed force was applied to the inner surface of the mounting hole. The unit force was used [7] for all elements to obtain stress distribution.

\section{The time course load}

The loads varying in time acting on elements of the helicopter Mi-24 were used to designate the operating profile of the helicopter and load measurements during the flight. 


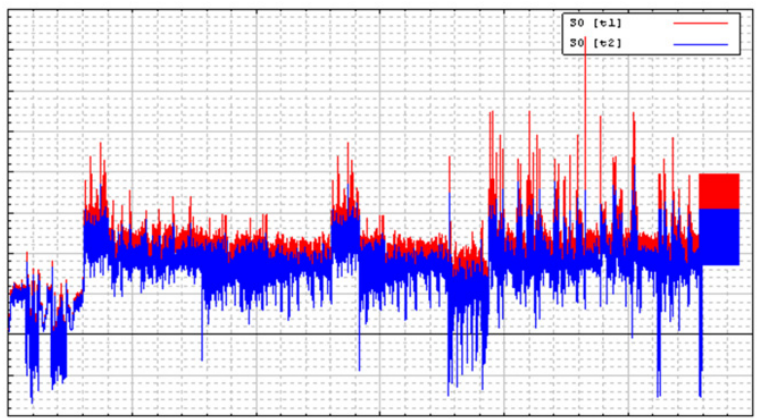

Fig. 12. The time history of load ELEMENT5

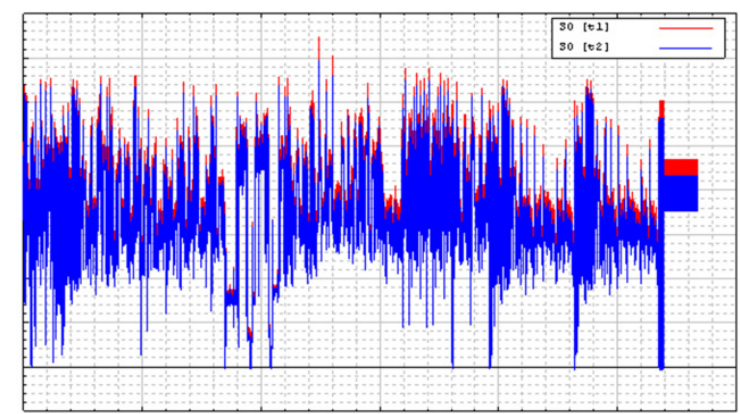

Fig. 13. The time history of load ELEMENT3

\section{Stress analysis}

The numerical fatigue calculations can be performed if the stress analysis is completed. Numerical stress analyses were carried out using the MSC.Marc software. The stress distributions under unit loads were obtained as results of linear static analyses.
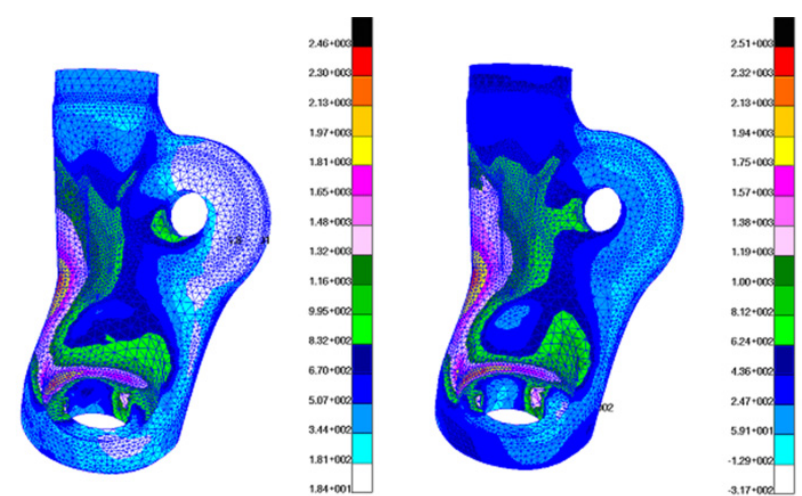

Fig. 14. Stress pattern a) reduced, b) max principal in ELEMENT3
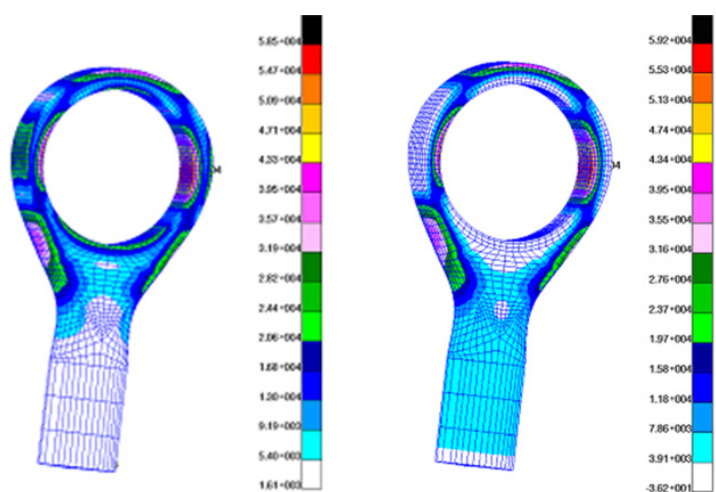

Fig. 15. Stress pattern a) reduced, b) max principal in ELEMENT7 (part 2) 
Tab. 2. Maximal value of reduced stress and maximal principal stress in elements under unit loads [7]

\begin{tabular}{|c|c|c|c|}
\hline No. & Element & $\begin{array}{c}\text { Maximal value of } \\
\text { material effort } \\
\text { [Pa] }\end{array}$ & $\begin{array}{c}\text { Maximal value } \\
\text { of principal stress } \\
{[\mathbf{P a}]}\end{array}$ \\
\hline 1 & ELEMENT2 & 2970 & 2880 \\
\hline 3 & ELEMENT3 & 2460 & 2510 \\
\hline 5 & ELEMENT4, ELEMENT5 & 26600 & 26600 \\
\hline 6 & ELEMENT7 (part 1) & 57200 & 55600 \\
\hline 7 & ELEMENT7 (part 2) & 58500 & 59200 \\
\hline 8 & ELEMENT1 (part 1) & 21400 & 21600 \\
\hline 9 & ELEMENT1 (part 2) & 39100 & 40900 \\
\hline 10 & ELEMENT6 (down load) & 13900 & 14700 \\
\hline 11 & ELEMENT6 (up load) & 13900 & 14200 \\
\hline
\end{tabular}

\section{Analysis of fatigue damage}

The fatigue damage calculations were performed using MSC.Fatigue software, which is closely integrated with the environment MSC.Patran.

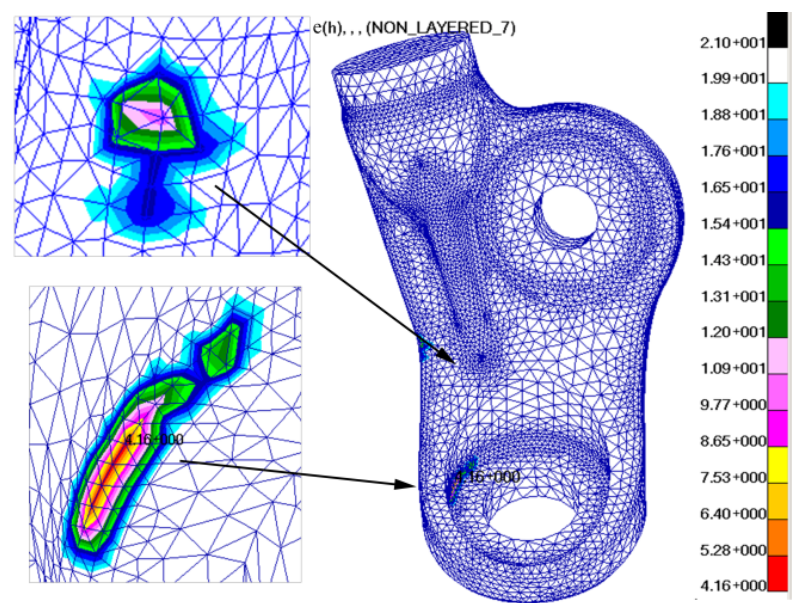

Fig. 16. The logarithm of the fatigue life of the element ELEMENT3

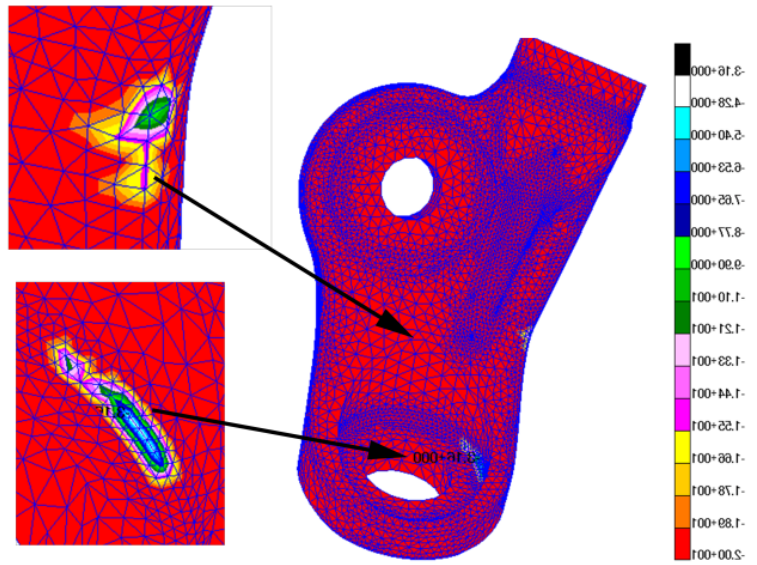

Fig. 17. The logarithm of the fatigue damage of the element ELEMENT3 


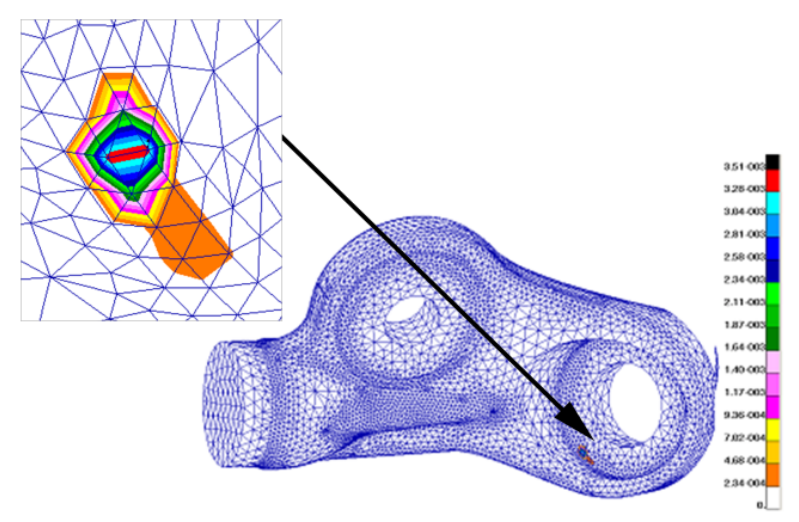

Fig. 18. Fatigue damage of element ELEMENT3

Tab. 3. Calculated fatigue life for elements [7]

\begin{tabular}{|c|c|c|}
\hline No. & Elements & Fatigue life [h] \\
\hline 1 & ELEMENT2 & 390 \\
\hline 3 & ELEMENT3 & 949 \\
\hline 5 & ELEMENT4, ELEMENT5 & 2332000 \\
\hline 6 & ELEMENT7 (part 1) & 583200 \\
\hline 7 & ELEMENT7 (part 2) & 583200 \\
\hline 8 & ELEMENT6 & 6727 \\
\hline
\end{tabular}

\section{CONCLUSION}

Fatigue life assessment was carried out for selected structural components of the Mi-24 helicopter structure. The results of the numerical calculations show that some elements have unlimited fatigue life but there are also elements where the significant fatigue damage can be a problem. The calculated fatigue life is highly dependent on assumptions made while developing the safe S-N curve. In this analysis, high safety factors result in short fatigue life estimations for some elements.

The Mi-24 helicopter is a safe life construction. The obtained results do not undermine the service life of the helicopter set by the manufacturer. The additional value of the work on stress analyses is developing by Polish Air Force Institute of Technology the NDT programme for the Mi-24 helicopter. Based on the stress analysis results, the NDT activity can be focused on the areas where the high stress levels occur. 


\section{REFERENCES}

[1] А. А. Лебедеb, Б. И. Коьальчук, Ф. Ф. Гигиняк, В. П. Ламашеьский (1983). Механические cbойстьа конструкционных материалоb при сложном напряженном состоянии Спраьочник. Академия Наук Украинской ССР Институт Проблем Прочности, Киеb Наукова Думка.

[2] Skorupiński, T., H., Aiken, W., S., Huston, W., B. (1953). Calibration of strain-gage installations in aircraft structures for the measurement of flight loads. Huston. REPORT NASA 1178.

[3] Rozmieszczenie punktów tensometrycznych na płatowcu śmigłowca Mi-24D nr fabryczny 103174 (nr boczny 174). Sprawozdanie Nr 149/31/2008 ITWL. Warszawa 2008.

[4] Skalowanie czujników tensometrycznych zabudowanych na elementach demontowalnych śmigłowca Mi-24D nr fabryczny 103174 ( $n r$ boczny 174). Sprawozdanie Nr 116/31/2008 ITWL. Warszawa 2008.

[5] Metodyka do przeprowadzenia skalowania czujników tensometrycznych śmigłowca Mi-24D nr fabryczny 103174. Metodyka Nr MB-4/31/2008 ITWL. Warszawa 2008.

[6] Sprawozdanie z pomiaru obciażeń konstrukcji śmigłowca Mi-24D systemem KAM-500. Sprawozdanie Nr 10/36/2009 ITWL. Warszawa 2009.

[7] Wykonanie analizy trwałości zmęczeniowej dla głównych elementów siłowych konstrukcji kadtuba śmigłowca Mi-24. Sprawozdanie Nr 114/31/2009 ITWL. Warszawa 2009.

[8] Wyznaczenie trwałości wybranych elementów struktury $w$ belce ogonowej $i$ końcowej śmigłowca Mi-14. Sprawozdanie Nr 28/31/2004 ITWL. Warszawa 2004. 